\title{
Technological aspects of lift-slab method in high-rise-building construction.
}

\author{
Pavel V. Gaidukov ${ }^{1, *}$, and Evgeny M. Pugach ${ }^{2}$ \\ ${ }^{1}$ Moscow State University of Civil Engineering, Yaroslavskoe shosse, 26, Moscow, 129337, Russia
}

\begin{abstract}
The utilization efficiency of slab lifting technology for highrise-building construction is regarded in the present article. The main problem of the article is organizing technology abilities indication, which proves the method application possibility. There is the comparing of lifting technologies and sequential concrete-frame extension, as follows: the first one: the parameters are defined, and the second one: the organizational model is executed. This model defines borders of the usage methods, as well. There is the mathematic model creating, which describes boundary conditions of the present technologies usage. This model allows to predict construction efficiency for different stored-number buildings.
\end{abstract}

\section{Introduction}

\subsection{Demand and high-rise construction development}

The process of the population urbanization has started in the middle of 20th century, which has led to the agglomeration cities with demanded infrastructure situated. This has made it possible to provide comfortable existence for the million population. However, the increase of the townscape areas has led to the sharp appreciation of the land properties cost for the major construction work objects in the investment appealing districts. This had effect on the square meters cost of the buildings. For example, $1 \mathrm{~m} 2$ cost of the one-roomed flat in Moscow has been changed from $600 \$$ to $4200 \$$ for the period from 2000 to 2017, agreeably. There is tendency on the infill areas organization by the mixed orientation highrise-complexes on the back of land value appreciation. These high-rise-complexes include as accommodation apartments as office spaces. All these factors has led to the high-riseconstruction demand on the territories that had been previously planless for such projects.

\subsection{Common problems of high-rise-building construction}

The main arresting factor of the high-rise-building construction is high-produced organization problem of the work performance [1]. Such type of building construction represents chain of cyclic processes held in the space on one typical floor territory. In its turn, the confined space does not allow to employ maximum quantity of the labor capacity

\footnotetext{
*karmodel@gmail.com
} 
and does not allow to make good use of building equipment, as well. Concrete works represent key technology operation on high-rise-building construction, which efficiency is expressed as form reuse. Mr. Hisham Abou Ibrahim and Mr. Farook Hamzeh in the article named as «Role of Formwork Systems in High-Rise Construction» note two problems of works organization, include the following:

The first one is: standard solutions represented as panel formwork that is held on the tower crane work, and thus the performance efficiency is decreased.

The second one is: the building height and organization complexity of lifting equipment additional installation points (except in the stiffening core) restrict no ability to launch any additional workflow for construction productivity increase connecting with the vertical construction transfer. The usage of the panel formwork is led to concrete defects precipitation. All of this demands to the additional resources mobilization for the defects isolation, as well. There is the proposed solution as self-climbing formwork set in the above article. [1.2] However it also has weaknesses such as necessity for horizontal form installation to concrete floor slabs. All of this turns us back to the question of lifting tackle usage.

The third one is: concrete mixture handling to the providing works level. Powerful concrete pump stations or organized interception points on the compounded floors, both are used for handling concrete to the high-levels of buildings. The usage of the way named as crane-bucket significantly reduces the concrete works performance.

Another side of the problem is hospitable working environment creation for labors. The necessity of the safety practices implementation during labors working on the height is led to the stuff movement restriction and to the checking performance increase by the technical customer, as well.

\subsection{Lift slab technology as high-rise-building construction problem solving}

In the present Article, the lift slab technology is proposed for above high-rise-building construction problem solving, which was first proposed by French engineer Lafarge. However, this solution could not be realized for the reason of the corresponding elevation equipment absence to lift such heavy constructions. The first multistory building was built in 1951 in the USA by the lift slab technology applying. Hereafter the same method was used during constructing buildings in Japan, Europe and the USSR. Summary of this technology is consisted in the enlarged block production, such as slab or a floor in general (slab and the higher walls) at the zero mark. In the following, they are lifted up along the piers, and excluding any horizontal moves, they are locked at the project mark, and then there is further vertical bearing support installation.

The present type preferences are the following

The first one is: flexibility of the bearing support material (rolled iron, prefabricated reinforced concrete, and monolith);

The second one is: flexibility of the space-planning decision;

The third one is: a great number of process operations that are performed at height absence; and

The forth one is: requirement for tower cranes installation, as well.

The lift method consists of the slab package production and moving up, in the following. General information about the building production technology is indicated in the article named as "New developments of lift slabs" by FRANK A. RANDALL, JR. The purpose of the present article is organizing technology abilities searching that prove the lift method utilization efficiency in the high-rise-building construction The present technology foundation is production of the precast flat slab conduit in the edge form at the zero mark 
and the preparation of the separation layer between several package slabs. Herewith the package slab must be capable of the main conditions requiring, as follows:

The first one: to exclude the bond above the contact slabs surface of different floors;

The second one: to possess abrasion and weather resistance. It means that it should not fail in the workers movements during reinforcing overlying slab, and lose its characteristics from the environmental factors;

The third one: to provide the production works continuity;

The forth one: to provide the constructions and concrete surfaces quality, as well.

These problems solution could be used separating layers preparation made of polyurethane film former lacquers [1.3]. Concreting and reinforcing of the construction are the same corresponding processes as using during building constructions by the standard methods. Exception to this applies collar installations into reinforcing cage, which are needful to lock slabs at the project marks. The sliding formwork usage is a rational way for the building stiffening core construction in real life of modern construction practice. Such type of methodic excepts any requirement in tower crane exploitation and interrupts for the concrete form panels movements [3].

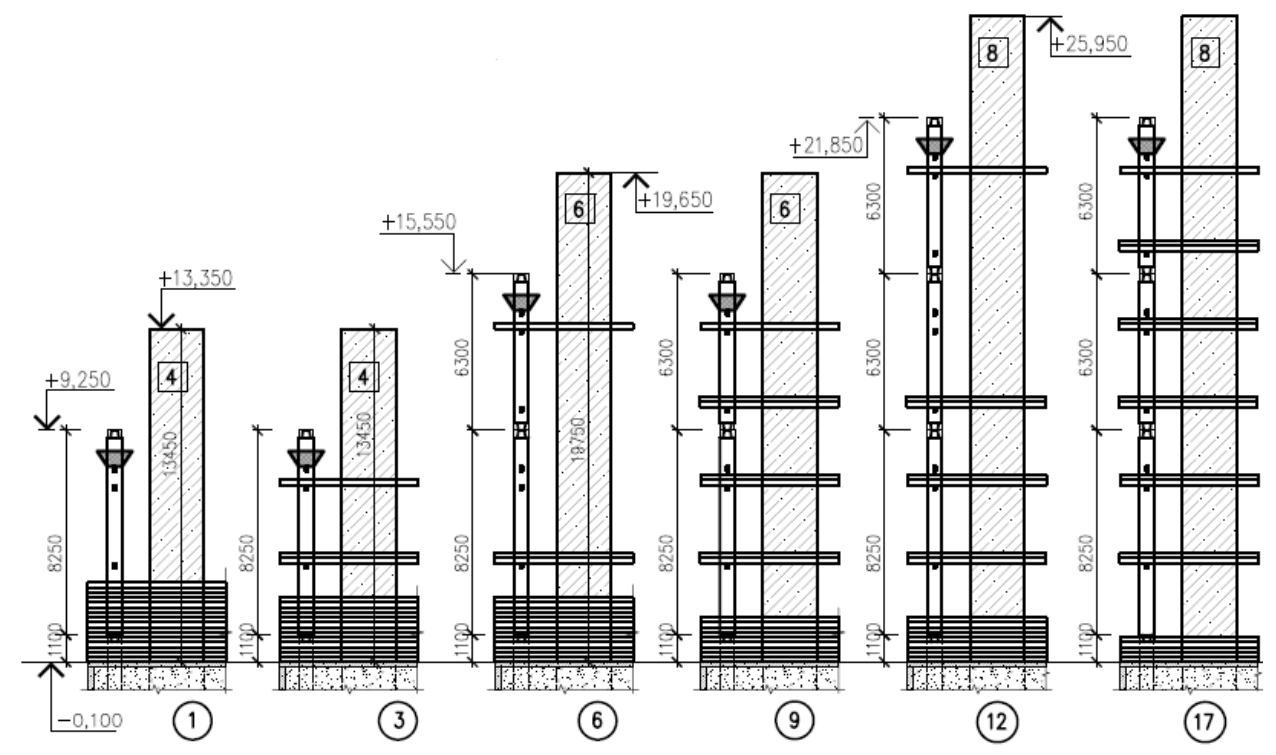

Fig. 1. Lifting model.

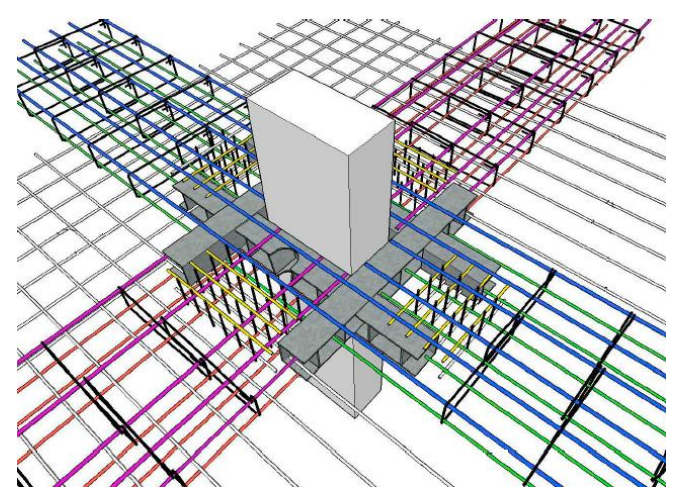

Fig. 2. Collar in the reinforcement. [3] 


\section{Materials and methods}

The analytic method to prove high efficiency of the high-rise-building construction is used in the present article. The reinforce concreate high-rise-building frame installation was comparing by slab lifting technology and sequential extension method, as well. Numerical investigations were conducted on basis of labor and machine time costs available data [4 ]. 30 -storied building was confirmed as searching model, and had the following parameters: 96 meters in height and its typical floor square was $784 \mathrm{~m} 2$.

\section{$3 \quad$ Results}

The labor input calculation and machining time cost, both, were represented for the propose of organizing model construction for lift-slab method and sequential extension technology (both are listed in table 1). There are main technology processes, which include in scope of works on building construction, set in the article. The technology operations, which are representative of both construction types indicating labor costs, are listed in table 1.

Table 1. Labor costs of the technology operations.

\begin{tabular}{|c|c|c|c|c|c|c|}
\hline \multirow[t]{2}{*}{ Processes name } & \multirow{2}{*}{$\begin{array}{l}\text { Unit of } \\
\text { measure }\end{array}$} & \multicolumn{2}{|c|}{ Scope of works } & \multirow[t]{2}{*}{ Providors } & \multicolumn{2}{|c|}{ Schedule time, hour } \\
\hline & & $\begin{array}{c}\text { Slab } \\
\text { lifting }\end{array}$ & $\begin{array}{c}\text { Sequential } \\
\text { extension }\end{array}$ & & $\begin{array}{c}\text { Slab } \\
\text { lifting }\end{array}$ & $\begin{array}{l}\text { Sequential } \\
\text { extension }\end{array}$ \\
\hline \multicolumn{7}{|c|}{ Vertical structures construction } \\
\hline $\begin{array}{l}\text { Colomn and } \\
\text { stiffening core } \\
\text { building }\end{array}$ & item & \multicolumn{2}{|c|}{1140} & & 465 & 476 \\
\hline $\begin{array}{l}\text { Stiffening core } \\
\text { building }\end{array}$ & $\mathrm{m}^{3}$ & \multicolumn{2}{|c|}{1582.5} & & 540 & 540 \\
\hline \multicolumn{7}{|c|}{ Slab construction } \\
\hline $\begin{array}{l}\text { Framework } \\
\text { handling }\end{array}$ & $\begin{array}{l}100 \\
\text { tonnes }\end{array}$ & 0.38 & 7.254 & & 3 & 130 \\
\hline $\begin{array}{l}\text { Form work } \\
\text { installation }\end{array}$ & $\mathrm{m}^{2}$ & 765.20 & 24180 & & 112 & 2440 \\
\hline Reinforse handling & $\begin{array}{l}100 \\
\text { tonnes }\end{array}$ & \multicolumn{2}{|c|}{10.41} & & 10 & 18 \\
\hline Slab reinforcement & tonne & \multicolumn{2}{|c|}{1010.72} & & 2646 & 2650 \\
\hline Collars installation & item & \multicolumn{2}{|c|}{2280} & & 200 & - \\
\hline $\begin{array}{l}\text { Concrete mixture } \\
\text { handling }\end{array}$ & $\mathrm{m}^{3}$ & \multicolumn{2}{|c|}{16.33} & & 36 & 40 \\
\hline Pouring concrete & $\mathrm{m}^{3}$ & \multicolumn{2}{|c|}{1608.75} & & 272 & 280 \\
\hline $\begin{array}{l}\text { Separation layer } \\
\text { preparation }\end{array}$ & $100 \mathrm{~m}^{2}$ & 241.80 & - & & 168 & - \\
\hline Sanding surfaces & $100 \mathrm{~m}^{2}$ & 241.80 & - & & 360 & - \\
\hline $\begin{array}{l}\text { Electromechanical } \\
\text { elevator installation }\end{array}$ & item & 1260 & - & & 88 & - \\
\hline Package lifting & cycle & 158 & - & & 32 & - \\
\hline \multicolumn{4}{|c|}{ Total } & & 4932.00 & 5558.00 \\
\hline
\end{tabular}


Analyzing data, it is possible to notice that the following type of works make the main difference in labor costs:

the first one is: floor shuttering construction works (2,328 hours);

the second one is: framework handling (127 hours); and

the third one is: the works which are not included in building frame extension works scope.

For illustration, the cyclogram of works performance is purposed (pic.3). This cyclogram measures both, as sequence of providing work, as rationality of one or another method usage. Picture 1 illustrates the line graphs of works cross at the level of 22 floor. The slab lifting is ahead of time the building frame works extension.

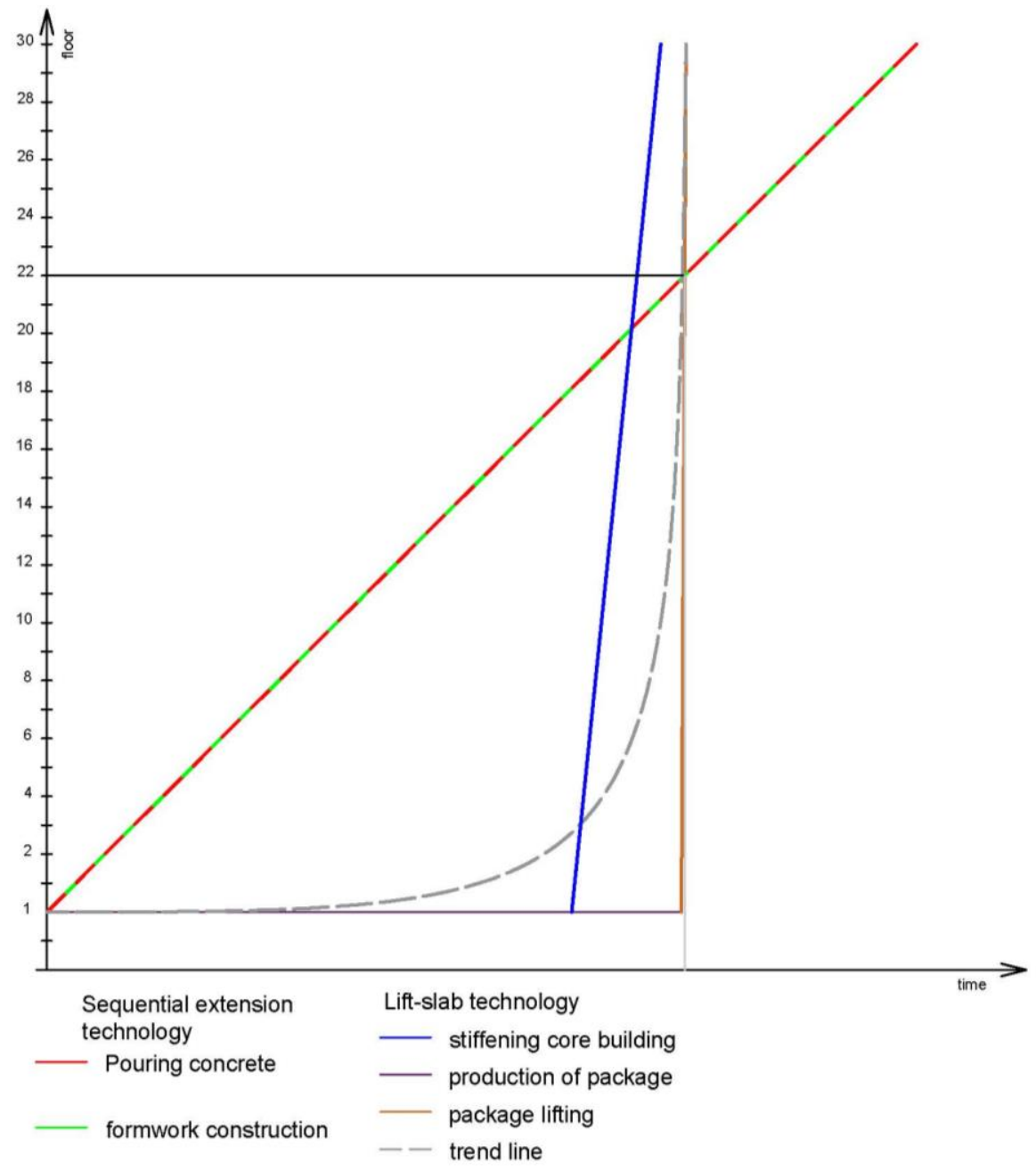

Fig. 3. Cyclogram of works performance.

This fact and the determined crossing point affords ground for function researching to prove taking the construction method. Approximation of the found functions allows us to assimilate the graph of lift-slab method made in system floors / time to the function 1, set as: $y=e^{\wedge}\left(x-0.01^{*} a\right)$. This also allows us to assimilate the building frame extension method to the function 2, set as: $y=x /(0.01 * a)$. (pic. 4$)$. 
There are the following shown the graph the

$\mathrm{X}$ (axis of abscissae) is shown as axis of time base;

$\mathrm{Y}$ (axis of ordinate) is shown as axis of floors;

$\mathrm{A}$ is shown as parameter equals to the labor effort for the associated building construction works (labor-days).

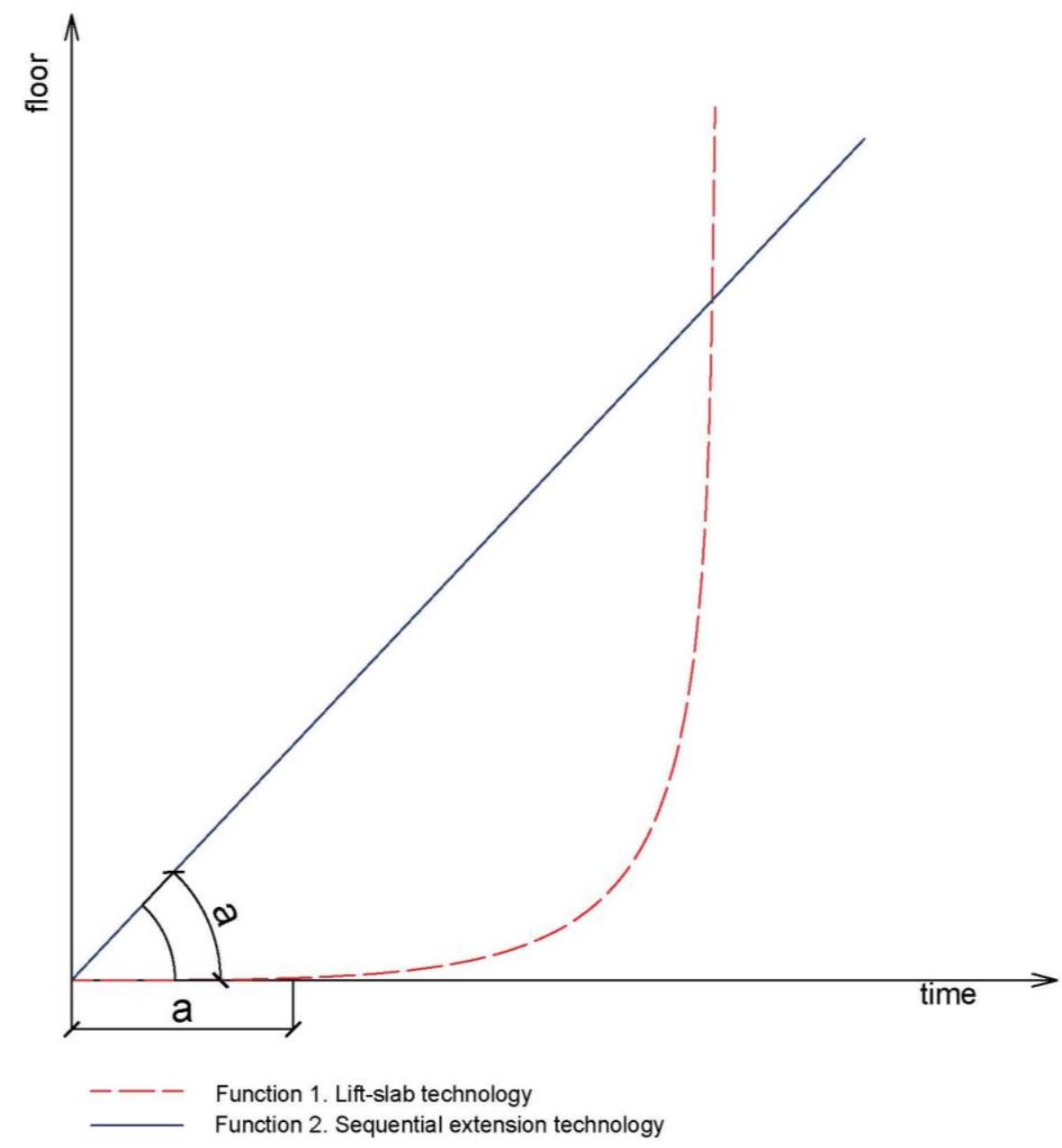

Fig. 4. Graph of the functions 1 and 2.

\section{Conclusions}

The crossing point founded by this way allows us to take stock the necessity of one or another method usage.

The choice problem of one or the other technologies is very subjective and it depends not only on the labor costs calculating. For each technology additional and external factors are very important. These factors are such as the following:

The first one is: construction site square;

The second one is: the number of work providers; and

The third one is: the organization possibility of safe working practices at height. 
The lift-slab method except the hazard factor for workers, which is connected with highrise operations and other associated works. However, this method does not allow to combine at the same time the following processes, such as finishing works, or engineering networks installation.

\section{References}

1. A. Hisham Abou Ibrahim1,2 and Farook R. Hamzeh11 Department of Civil and Environmental Eng ineering, American University of Beirut, Lebanon Role of Formwork Systems in High-Rise Construction. Available from: Role of Formwork Systems in High-Rise Construction [accessed Jan 15 2018].

2. A. Frank, J. Randall, Structural Engineer Concrete Construction, (1981)

3. A.O. Saakyan, R.O. Saakyan, S.Kh. Shakhnazaryan Vozvedenie zdaniy i sooruzheniy metodom pod"ema. (Stroyizdat, Moscow, 1985)

4. Edinye Normy i rastsenki na stroitel'no-montazhnye raboty. Body E-1-7, E-4. (Glavstroy Ministerstva stroitel'stva SSSR 1972)

5. J.I. Potapova, Method Of Lifting Of Overlappings - Town-Planning Accent To Low Budget Habitation, (The Rostov State Building University, Rostov-on-Don)

6. M. Ashraf et al Adapting Lift-Slab Technology To Construct Submerged Pile Caps, Journal Of Construction Engineering And Management (2000) 